\title{
Article
}

\section{A Microencapsulation Method for Delivering Tetrodotoxin to Bivalves to Investigate Uptake and Accumulation}

\author{
Laura Biessy $^{1,2,3, * \mathbb{C}}$, Kirsty F. Smith ${ }^{1}$, Susanna A. Wood $^{1}{ }^{1}$, Annabel Tidy ${ }^{4}$, Roel van Ginkel ${ }^{1}$, \\ Joel R. D. Bowater ${ }^{1}$ and Ian Hawes ${ }^{2}$ (D) \\ 1 Cawthron Institute, Coastal and Freshwater, Nelson 7010, New Zealand; \\ kirsty.smith@cawthron.org.nz (K.F.S.); susie.wood@cawthron.org.nz (S.A.W.); \\ roel.vanginkel@cawthron.org.nz (R.v.G.); joel.bowater@cawthron.org.nz (J.R.D.B.) \\ 2 Department of Biological Sciences, University of Waikato, Hamilton 3216, New Zealand; \\ ian.hawes@waikato.ac.nz \\ 3 New Zealand Food Safety Science \& Research Centre, Palmerston North 4442, New Zealand \\ 4 School of Geography, Earth and Environmental Sciences, University of Birmingham, Birmingham B15 2TT, \\ UK; a.tidy@bham.ac.uk \\ * Correspondence: laura.biessy@cawthron.org.nz; Tel.: +64-(0)3-548-2319
}

check for updates

Citation: Biessy, L.; Smith, K.F.; Wood, S.A.; Tidy, A.; van Ginkel, R.; Bowater, J.R.D.; Hawes, I. A

\section{Microencapsulation Method for}

Delivering Tetrodotoxin to Bivalves to Investigate Uptake and Accumulation. Mar. Drugs 2021, 19,

33. https://doi.org/10.3390/ md19010033

Received: 3 December 2020 Accepted: 11 January 2021 Published: 13 January 2021

Publisher's Note: MDPI stays neutral with regard to jurisdictional clai$\mathrm{ms}$ in published maps and institutional affiliations.

Copyright: $\odot 2021$ by the authors. Licensee MDPI, Basel, Switzerland. This article is an open access article distributed under the terms and conditions of the Creative Commons Attribution (CC BY) license (https:// creativecommons.org/licenses/by/ $4.0 /)$.

\begin{abstract}
Most marine biotoxins are produced by microalgae. The neurotoxin tetrodotoxin (TTX) has been reported in many seafood species worldwide but its source is unknown, making accumulation and depuration studies in shellfish difficult. Tetrodotoxin is a water-soluble toxin and cannot be directly ingested by shellfish. In the present study, a method was developed which involved binding TTX to solid particles of humic acid and encapsulating them in agar-gelatin capsules. A controlled quantity of TTX-containing microcapsules (size range 20-280 $\mu \mathrm{m}$ ) was fed to Paphies australis, a bivalve known to accumulate TTX in the wild. The TTX-containing microcapsules were fed to $P$. australis every second day for 13 days. Ten $P$. australis (including five controls fed non-toxic microalgae) were harvested after 7 days and ten after 13 days. Paphies australis accumulated TTX, reaching concentrations of up to $103 \mu \mathrm{g} \mathrm{kg}^{-1}$ by day 13, exceeding the European Food Safety Authority recommended concentration of $44 \mu \mathrm{g} \mathrm{kg}^{-1}$ in shellfish. This novel method will allow future studies to explore the effects, accumulation and depuration rates of TTX in different animals and document how it is transferred through food webs.
\end{abstract}

Keywords: bioaccumulation; feeding experiment; humic acid; marine toxin; shellfish

\section{Introduction}

Shellfish are a rich source of protein, essential minerals, vitamins and are an important food source worldwide [1]. However, bivalves filter large volumes of water and can concentrate contaminants including bacterial pathogens and phycotoxins [2]. With over 66 million tonnes of shellfish now consumed by humans annually, the risk of poisoning through contaminated seafood is an increasing public health concern $[3,4]$. With regards to phycotoxins (biotoxins produced by microalgae), the risk of poisoning increases exponentially during harmful algal blooms (HABs), when microalgal populations form dense concentrations of cells and sometimes visible water discolouration [5]. HABs have negative environmental impacts and can cause mass mortalities of fish, birds and marine mammals, and human illness [1], when they produce biotoxins that contaminate seafood through biomagnification up the food web [6]. About 300 marine microalgal species are known to produce biotoxins and more than 100 of these can cause intoxication or even death in humans and animals [6].

The microalgal species responsible for producing most of the known biotoxins have been identified. For example, in the marine environment, saxitoxin (STX), a potent neurotoxin regularly present in edible shellfish and responsible for paralytic shellfish poisoning, is produced by dinoflagellates species from the genera Alexandrium, Gymnodinium, 
Centrodinium and Pyrodinium [7-10]. Saxitoxin is also produced by freshwater cyanobacteria, the most common genera being Anabaena, Aphanizomenon, Cylindrospermopsis, Lyngbya and Planktothrix [11-13]. The fate of microalgal biotoxins in marine and freshwater organisms has been evaluated in a number of species. For example, green-lipped mussels Perna viridis were exposed to STX-producing dinoflagellate Alexandrium fundyense that were then fed to black sea bream Acanthopagrus schlegeli and the accumulation, distribution, transformation, and elimination of STX in specific organs were evaluated [14]. The hepatopancreas in the mussels and the viscera in the fish accumulated most of the STX. Differences in uptake, distribution, and elimination of STX were observed between mussels and fish, and this may influence the trophic transfer of microalgal toxins in marine organisms. Pereira et al. [15] evaluated the accumulation and depuration of STX by a freshwater mussel Anodonta cygnea exposed to the STX-producing cyanobacterium Cuspidothrix (Aphanizomenon) issatschenkoi, and concluded that when removing/metabolizing $40 \%$ of the daily toxin consumed, the feeding behaviour of the mussels was affected (i.e., erratic feeding patterns and lower clearance rate of the toxic species).

While the sources and pathways of many marine biotoxins are well known, the origin of tetrodotoxin (TTX), a widespread and potent neurotoxin naturally occurring in organisms from marine, freshwater and terrestrial environments, remains uncertain [16]. There is contradictory evidence regarding whether the source of TTX is exogenous or endogenous, and the pathways and mechanisms through which TTX is incorporated in the food web are unknown [17]. The wide distribution of TTX in many genetically unrelated species suggests that the toxin comes from an exogenous source such as accumulation through diet or symbiotic bacteria $[18,19]$ with reports in the literature of at least 150 TTX-producing bacterial strains [20]. However, there is also evidence for an endogenous source in terrestrial species such as frogs or newts [21,22]. The neurotoxin is responsible for 30-50 global human intoxications every year and has the highest fatality rate of all marine biotoxins, mainly from pufferfish (e.g., fugu) consumption [23]. Tetrodotoxin also occurs in marine shellfish and has been reported in 21 species of bivalves and edible gastropods from ten countries since the 1980s [24]. The risk of TTX intoxication to humans via shellfish cannot be ignored due to the high and increasing amounts consumed worldwide. Understanding the accumulation of TTX in the marine food web will help evaluate and reduce this risk. Without a known producer, studies which explore TTX accumulation in bivalves are very challenging. To date, there have been no feeding studies in bivalves, but feeding studies involving other organisms such as the sea-slug Pleurobranchaea maculata [25] and the pufferfish Takifugu niphobles [26] suggested that TTX is accumulated via the diet.

A possible option for administrating toxins to bivalves is through microencapsulation. This involves the encapsulation of a solid within a thin protective coating, creating small particles [27]. This technology has been readily used within food and pharmaceutical industries as it allows a core material to be completely isolated from the external environment [28]. The technique has recently been used to provide sustained and controlled release of bioactives in aquaculture [29]. Microencapsulation has been used to feed live microalgae to the oyster Crassostrea gigas [27] but the present study is the first which uses the encapsulation of a pure toxin which is then fed to shellfish. Tetrodotoxin is a relatively small, water-soluble molecule [30], making it impossible to directly encapsulate TTX without it being bound to a solid first.

This study aimed to (1) develop a method to encapsulate TTX into a food suitable for bivalves and (2) feed known amounts of TTX to a bivalve species to determine accumulation. This technique would allow future studies to investigate the effects, accumulation and depuration rates of the neurotoxin in different animals, as well as its bioaccumulation in higher organisms via feeding of contaminated shellfish. This method could then be applied to other biotoxins where the source is unknown, isolation of the causative organisms is challenging or production of the biotoxin is not stable. In this experiment, TTX bound to humic acid was encapsulated in an agar-gelatin solution. A known quantity of the TTX 
microcapsules were fed to Paphies australis, an endemic New Zealand clam that has been shown to accumulate high TTX concentrations in the wild [31,32].

\section{Results}

\subsection{Microscopic Characterization of Microcapsules}

To develop the encapsulation method, microalgae that could be observed under the microscope were first used to determine if cells could be encapsulated and if the capsules were impermeable.

The microscopic analysis showed the microcapsules were intact and approximately spherical (Figure 1). The encapsulation of the live Alexandrium minutum cells was successful (Figure 1A) and the micro-algae survived the high temperatures of the encapsulation and stayed in the capsules until they disintegrated $(42 \mathrm{~h})$. The microscopic analysis also showed that the humic acid was encapsulated (Figure 1B,C). The smallest capsules agglutinated to each other but were easily disrupted with gentle agitation. The capsules stayed intact for a minimum of $34 \mathrm{~h}$, their diameters ranged from 20 to $280 \mu \mathrm{m}$ and $>85 \%$ contained humic acid particles. Each fresh batch of capsules (made just prior to feeding) varied between 18,000 and 33,000 capsules per $\mathrm{mL}$ and ca. $75 \mathrm{~mL}$ of concentrated capsule solution was produced, containing ca. $506 \mu \mathrm{g}$ TTX per $\mathrm{L}^{-1}$. On average, each P. australis filtered the $100 \mathrm{~mL}$ of solution ( $93 \mathrm{~mL}$ of microalgae with $7 \mathrm{~mL}$ of TTX capsules) within $4 \mathrm{~h}$. Capsules containing humic acid particles were found partially digested in the digestive glands of P. australis (Figure 1D), showing that the clams were capable of filtering and digesting the agar-gelatin capsules.

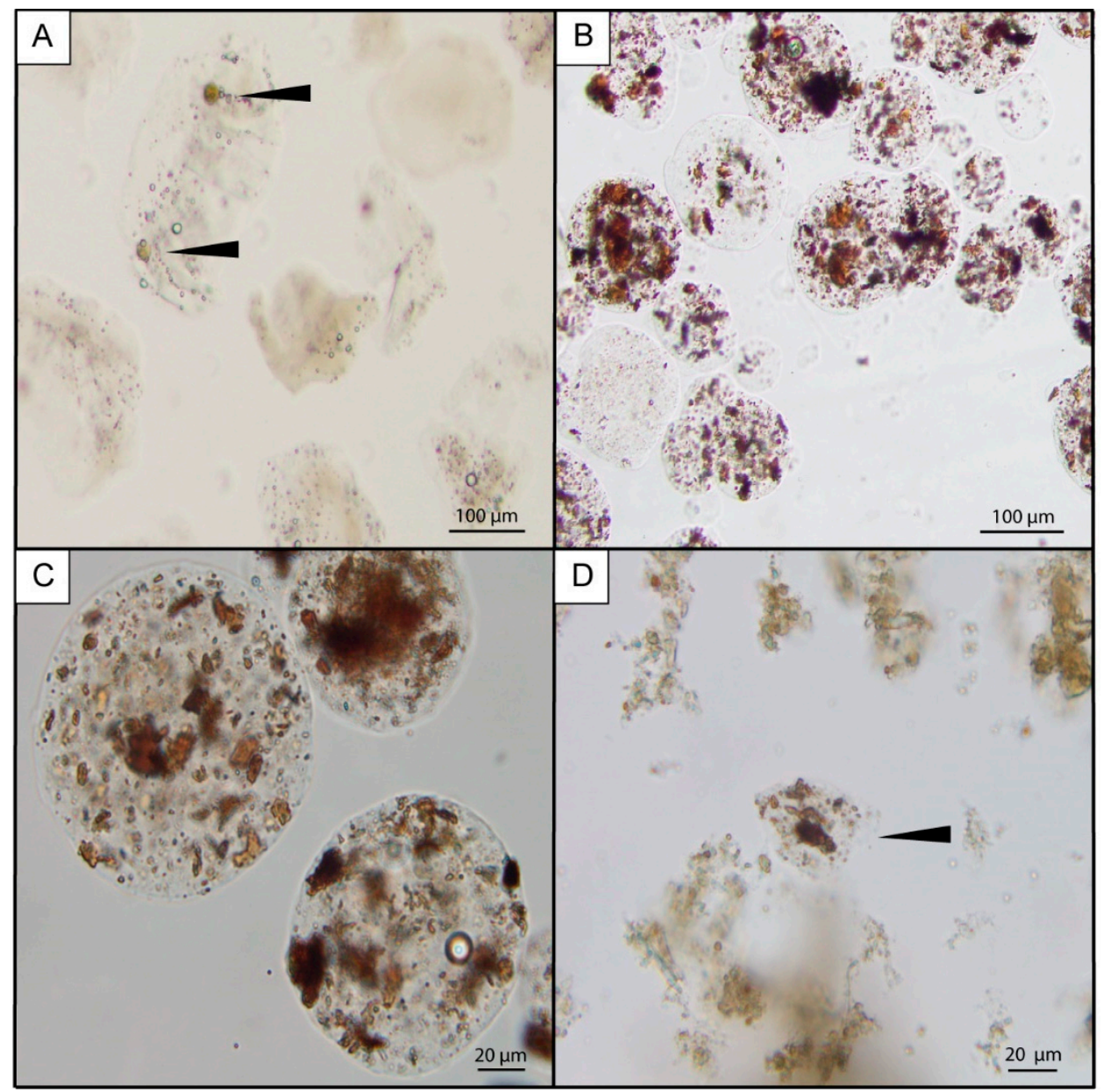

Figure 1. Agar-gelatin microcapsules containing Alexandrium minutum cells ((A); black arrows) and humic acid (the brown solids; (B-D)). The black arrow in (D) shows a partially digested capsule containing humic acid that was found in the digestive gland of a Paphies australis. 


\subsection{Tetrodotoxin Encapsulation}

The next step was to validate that TTX was binding to humic acid before adding it to the capsules. The results showed that ca. $70 \%$ of the TTX was bound to the humic acid and that most (ca. 80\%) of the bound TTX was released after addition of the formic acid to break the ionic bond between TTX and the humic acid, the same way as it would in the acidic digestive glands of $P$. australis (Table 1).

Table 1. Tetrodotoxin (TTX) concentrations in solution at various stages in the testing of adsorption and release (under acidic conditions) from humic acid.

\begin{tabular}{cc}
\hline Sample & TTX Concentration (ng $\mathbf{~ L ~}^{-\mathbf{1}}$ ) in Solution \\
\hline TTX in water & $102.3 \pm 5.5$ \\
TTX in water + humic acid & $29.7 \pm 1.8$ \\
TTX in water + humic acid + formic acid & $82.7 \pm 2.1$ \\
\hline
\end{tabular}

\subsection{Feeding Experiment}

The culture of the microalga Isochrysis gabana did not contain any TTX. The environmental controls (wild P. australis harvested from Delaware Bay, Nelson, New Zealand) tested positive for TTX with an average of $15 \mu \mathrm{g} \mathrm{kg}^{-1}$. The TTX concentrations in the experimental controls remained stable during the feeding experiment (average of 17 and $15 \mu \mathrm{g} \mathrm{kg}^{-1}$ in whole $P$ australis after 7 and 13 days respectively). TTX concentrations in the different samples of the experimental controls also remained constant with the digestive glands and siphons (DGS) containing an average of $44 \mu \mathrm{g} \mathrm{kg}^{-1}$ after 7 days and $39 \mu \mathrm{g}$ $\mathrm{kg}^{-1}$ after 13 days and the "rest" of the organs containing $9.8 \mu \mathrm{g} \mathrm{kg}{ }^{-1}$ after 7 days, and $7.5 \mu \mathrm{g} \mathrm{kg}^{-1}$ after 13 days (Figure 2).
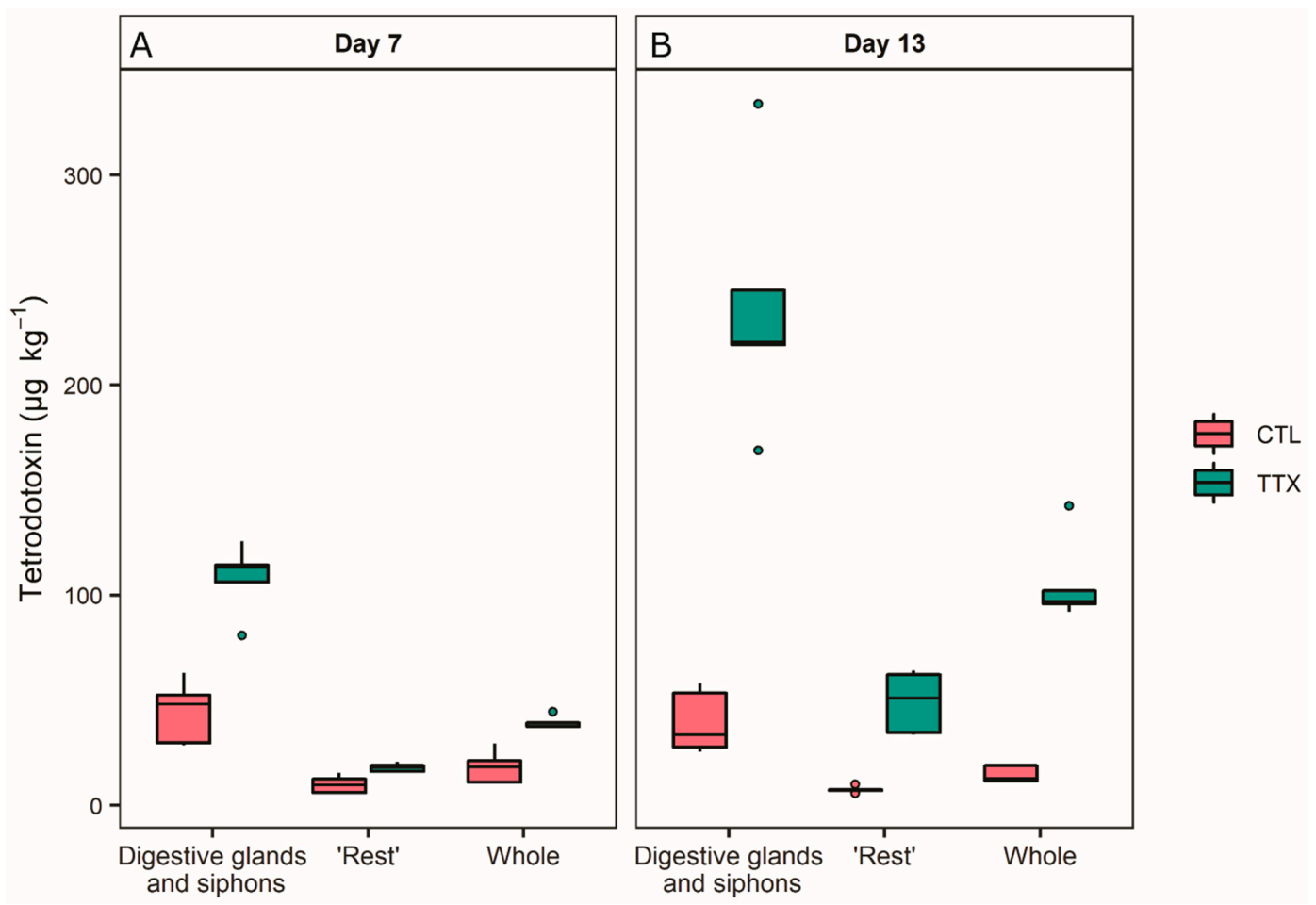

Figure 2. Tetrodotoxin (TTX) concentrations in experimental controls (CTL) and treatment samples (TTX) for the two tissue types (combined digestive gland and siphon, and everything else "rest") and "whole" Paphies australis $(n=5)$ individuals after being fed controlled amounts of TTX every three days for 7 (A) and 13 days (B). The solid black line shows median, box shows 1st and 3rd quartiles, whiskers extend to the last data point within 1.5 times the inter-quartile range. Dots outside the whiskers are considered as outliers. 
Tetrodotoxin concentrations were significantly higher in the DGS of P. australis fed TTX for 7 days (average of $108 \mu \mathrm{g} \mathrm{kg}-1, p=0.001$ ) and 13 days (average of $238 \mu \mathrm{g} \mathrm{kg}^{-1}, p<0.0001$ ), compared to the experimental control organisms fed microalgae only (average of $44 \mu \mathrm{g} \mathrm{kg}^{-1}$ ). The TTX concentration was also significantly higher in the "rest" samples compared to the controls (average of $9 \mu \mathrm{g} \mathrm{kg}^{-1}$ ) after 7 days of feeding (average of $18 \mu \mathrm{g} \mathrm{kg}^{-1}, p=0.026$ ) and after 13 days (average of $49 \mu \mathrm{g} \mathrm{kg}^{-1}, p<0.0001$ ). The P. australis accumulated more TTX over time, the concentration was significantly higher in DGS and in the "rest" samples at day 13 compared to day 7 ( $p=0.0136$ and $p=0.001$, respectively; Figure 2). TTX concentrations in whole P. australis (calculated by summing results from DGS and rest samples on a pro-rata weight) reached $39.2 \mu \mathrm{g} \mathrm{kg}^{-1}$ after 7 days and $105.9 \mu \mathrm{g} \mathrm{kg}-1$ after 13 days.

A mixed-effect linear model showed that there was no significant difference in the control groups from the DGS and the "rest" groups ( $p=0.999$ and $p=0.993$, respectively) between days 7 and 13 (Table 2). The interactions between days, organs and treatment (TTX versus experimental controls) were not significant. There were significant differences in the control treatments between the DGS and "rest" sample types from both sampling days ( $p<0.0001$ for days 7 and 13) and there were significant differences between the two sample types and controls $(p<0.0001)$ and at each day $(p<0.0001)$.

Table 2. Pairwise comparisons (Tukey HSD test) of mean tetrodotoxin concentrations in Paphies australis during the feeding experiment, among days, sample type and treatments (CTL = controls fed microalgae only, TTX = organisms fed tetrodotoxin capsules and microalgae, DGS = Digestive gland and siphons pooled together). Bolded values represent statistically significant differences $(p<0.05)$.

\begin{tabular}{|c|c|c|c|c|c|c|c|c|c|c|c|c|c|c|}
\hline & & & \multicolumn{6}{|c|}{ Day 7} & \multicolumn{6}{|c|}{ Day 13} \\
\hline & & & \multicolumn{2}{|c|}{ DGS } & \multicolumn{2}{|c|}{ Rest } & \multicolumn{2}{|c|}{ Whole } & \multicolumn{2}{|c|}{ DGS } & \multicolumn{2}{|c|}{ Rest } & \multicolumn{2}{|c|}{ Whole } \\
\hline & & & CTL & TTX & CTL & TTX & CTL & TTX & CTL & TTX & CTL & TTX & CTL & TTX \\
\hline \multirow{6}{*}{ Day 7} & & CTL & & 0.022 & $<0.0001$ & 0.0052 & & & & & & & & \\
\hline & DGS & TTX & & & $<0.0001$ & $<0.0001$ & & & & & & & & \\
\hline & Reste & CTL & & & & 0.0444 & & & & & & & & \\
\hline & Rests & TTX & & & & & & & & & & & & \\
\hline & & CTL & & & & & & 0.0055 & & & & & & \\
\hline & Whole & TTX & & & & & & & & & & & & \\
\hline \multirow{5}{*}{$\begin{array}{c}\text { Day } \\
13\end{array}$} & & CTL & 0.9999 & 0.0005 & $<0.0001$ & 0.0234 & & & & $<0.0001$ & $<0.0001$ & $<0.0001$ & & \\
\hline & DGS & TTX & $<0.0001$ & 0.0131 & $<0.0001$ & $<0.0001$ & & & & & 0.9607 & $<0.0001$ & & \\
\hline & & CTL & $<0.0001$ & $<0.0001$ & 0.9927 & 0.0038 & & & & & & $<0.0001$ & & \\
\hline & Rests & TTX & 0.9998 & 0.0136 & $<0.0001$ & 0.001 & & & & & & & & \\
\hline & Whole & $\begin{array}{l}\text { CTL } \\
\text { TTX }\end{array}$ & & & & & $\begin{array}{l}0.9998 \\
<0.0001\end{array}$ & $\begin{array}{c}0.001 \\
0.0011\end{array}$ & & & & & & $<0.0001$ \\
\hline
\end{tabular}

Based on the amount of TTX provided at each feeding (ca. $506 \mu \mathrm{g} \mathrm{L}{ }^{-1}$ in the capsule solution), the $P$. australis accumulated on average $0.5 \%$ of the TTX provided for the first 7 days $(0.6 \%$ in the DGS and $0.32 \%$ in the "rest") and $0.98 \%$ on average after 13 days $(0.88 \%$ in the DGS and $0.42 \%$ in the "rest").

\section{Discussion}

The overarching aim of this study was to develop a method to encapsulate TTX in a way that made it possible to feed it in a controlled experiment to bivalves. Achieving this would allow studies on accumulation rates and add to evidence that TTX might be obtained through the food web. In this study, we used the clams $P$. australis, which are endemic to New Zealand and have been shown to accumulate TTX to reasonably high levels in the environment as our test organisms [32].

An initial concern when generating the microcapsules was that the wild P. australis had never been exposed to artificial food. The microcapsules containing TTX needed to be within the size range of particles that the organisms were able to ingest. Most bivalves filter particles greater than $5 \mu \mathrm{m}$ in diameter with nearly $100 \%$ efficiency [33] and 
several studies reported an efficient uptake of particles with diameters of 200 to $300 \mu \mathrm{m}$ in bivalves $[27,34]$. The microcapsules produced in the present study were within this size range $(20$ to $280 \mu \mathrm{m})$. Our observations supported the posit that the microcapsules were of a digestible size as the capsule-microalgae solution was filtered and the water was clear within $4 \mathrm{~h}$ and microscopic analysis showed capsules present in the digestive glands of P. australis.

The encapsulation process used in our study did not destroy or degrade the TTX as evidenced by the high concentration remaining in the final capsule solution. Additionally, the agar, gelatin and humic acid were not detrimental to $P$. australis survival or feeding, as all the individuals stayed healthy for the duration of the experiment. The advantage of using an agar-gelatin capsule is that it is stable (the capsules stayed intact for at least $34 \mathrm{~h}$ ) and impermeable, but easily dissolves when placed in a slightly acidic medium (i.e., the digestive system of bivalves). The use of humic acid as a solid binding agent was an important adaptation which allowed the water-soluble TTX to be contained inside a microcapsule instead of leaking out into the water.

Once the encapsulation method was developed and the ingestion of TTX-filled capsules by $P$. australis was confirmed, the second aim of this study was to feed them a controlled amount of TTX and investigate its accumulation rate. TTX has been detected in all $P$. australis tested in previous studies $[31,32,35]$ and we anticipated to detect the low concentrations of TTX (average of $15 \mu \mathrm{g} \mathrm{kg}^{-1}$ ) found in the "environmental control" P. australis. The amounts detected after both seven ( 3 feedings) and 13 days ( 5 feedings) were significantly higher than this and were on par with concentrations recently detected in wild $P$. australis in New Zealand $[35,36]$. An exception to this was the detection of very high concentrations ( $800 \mu \mathrm{g} \mathrm{kg}^{-1}$, i.e., 80 -fold higher than detected in other studies) of TTX in 2014 [32]. One hypothesis could be that the P. australis in that study had consumed a highly toxic source such as eggs or larvae from the sea-slug Pleurobranchaea maculata or flatworm Stylochoplana sp. that have been shown to contain extremely high levels of TTX [37].

The concentrations measured in whole $P$. australis after only 13 days of feeding $\left(103 \mu \mathrm{g} \mathrm{kg}^{-1}\right)$ were well above the European Food Safety Authority recommendation concentration of $44 \mathrm{\mu g} \mathrm{kg}^{-1}$ for TTX in shellfish without seeing adverse effects in human health [38]. This result shows that monitoring TTX concentrations in edible bivalves is important and should be established in areas or countries where shellfish have been shown to contain high TTX concentrations and are regularly harvested for consumption. Foodborne TTX is a realistic scenario as previous studies have shown that its source in bivalves is likely exogenous, with reports of bacterial species such as Vibrio and Pseudomonas $[16,20]$ or cyanobacteria, especially picocyanobacteria $[36,39]$ suggested as potential producers. If one of these species is confirmed as the producer, the risks of TTX in edible seafood are likely to increase with climate change as both cyanobacteria and bacteria thrive at warmer temperatures $[40,41]$. This study shows that $P$. australis can accumulate TTX from an external source and strengthens the hypothesis that bivalves accumulate TTX from their diet.

The method developed in this study can now be used to feed a range of bivalve species to determine if they can also accumulate TTX to concentrations above the recommended threshold. In addition to accumulation rates, depuration could also be studied, which will add valuable information for the management of commercial species (i.e., blue mussel, oysters) that have been shown to accumulate TTX in several countries [24]. Investigating TTX accumulation in a wide range of bivalves will also assist in understanding the mechanisms of TTX accumulation, such as the potential presence of a TTX-binding protein. Lastly, this method will also pave the way for further studies that explore TTX accumulation through the food web. For example, once the shellfish have accumulated the TTX, these could be fed to higher trophic organisms in the food web (e.g., fish). Similar studies have previously been undertaken, for example, Oikawa et al. (2005) investigated the accumulation and depuration rates of STX in crabs that were fed toxic mussels after being exposed to toxic cyanobacteria [42]. 
We estimated that only $0.5-1 \%$ of the TTX administered was accumulated by P. australis. The low accumulation relative to the amount filtered could be due to some TTX molecules breaking down with the acid from the P. australis digestive system. Unfortunately, we were unable to test the amount of TTX in the faeces, so the quantity of TTX directly excreted is unknown. It is also possible that $P$. australis are only capable of accumulating a certain amount of TTX. It has been hypothesised that these bivalves contain unique TTX-binding proteins similar to those found in pufferfish and crabs $[31,43,44]$ that allow them to store the toxin in certain organs. It is possible that the TTX-binding protein could become saturated when exposed to a high amount of the toxin in a short amount of time. The low accumulation could also be due to the $20 \%$ of TTX remaining bound to the humic acid and not being absorbed by the bivalves once ingested. Despite the low accumulation rate of TTX observed in this study, the fact that $P$. australis are slow detoxifiers/depurators for TTX [31], suggests that for this species to reach similar concentrations in the wild, the producer would either be present most of the time but in low quantities, or only present occasionally but in higher concentrations. The amount of TTX filtered in the wild could thus be very high for a brief period and the P. australis retains the toxin for a very long time. Additionally, the bivalve species may accumulate a TTX precursor molecule and biosynthesize it to TTX, making the TTX producer very difficult to find.

In this study, the siphons and the digestive glands accumulated more TTX than the remaining tissue, corroborating with previous studies that reported these organs accumulated the highest amount of TTX in the wild [45]. The "rest" group did not show an increase in TTX accumulation after 7 days of feeding but did increase after 13 days, suggesting that the toxin is migrating between the clam's organs as it was previously indicated [31]. Studies have found reduced predation on shellfish with high STX concentrations [46,47], suggesting that the concentrated levels of TTX within P. australis' siphons may be to protect the vulnerable organ which protrudes out of the sand in their natural environment. Previous studies on bivalves have shown greater toxin accumulation in the digestive glandstomach complex and viscera which may contribute up to $98 \%$ of the total toxin, but in some bivalves, a reversal of toxin content from the digestive gland and viscera has been observed, with toxins migrating to alternative tissues over time $[48,49]$. To fully understand toxin micro-distribution within each species from these experiments, it would be necessary to undertake further fine-scale dissections of each organ as well as feeding for a longer period to allow for toxin exchange between tissues to occur. However, our demonstration of initial toxin accumulation occurring within the digestive glands is useful for the analysis of wild populations, potentially inferring the recency of a contamination event and the occurrence of ongoing toxin uptake.

\section{Materials and Methods}

\subsection{Paphies australis Collection and Acclimation}

Adult Paphies australis $(n=30)$ of similar size (ca. $40 \mathrm{~mm}$ long) were collected from Delaware Bay (Nelson, New Zealand; $41^{\circ} 09^{\prime} \mathrm{S}, 173^{\circ} 27^{\prime}$ E) between March and August 2020, chilled (ca. $8{ }^{\circ} \mathrm{C}$ ) and transported to the laboratory (Cawthron Institute, Nelson, New Zealand) within one hour. The shells were scrubbed and rinsed with sterile seawater to remove biofouling. Control samples (hereafter environmental controls; $n=5$ ) were stored frozen $\left(-20^{\circ} \mathrm{C}\right)$ until later TTX analysis to ensure that there was no or only very low TTX in the environmental population. The remaining individuals were placed in aquariums (15-L) which had been thoroughly cleaned and rinsed pre-experiment using detergent and bleach $(10 \%)$. These were maintained with a recirculating flow of seawater and continuous aeration at $18 \pm 1{ }^{\circ} \mathrm{C}$ with a 14:10 $\mathrm{h}$ light:dark cycle. The bivalves were left to acclimatize for one week and fed the microalgal species Isochrysis galbana $\left(2 \mathrm{~L}\right.$, ca. $12 \times 10^{6}$ cells mL $\left.\mathrm{mL}^{-1}\right)$ every second day. 


\subsection{Microencapsulation Method Development}

\subsubsection{Micro-Algal Encapsulation}

To develop the encapsulation method, the dinoflagellate Alexandrium minutum (CAWD12, maintained in the Cawthron Institute Culture Collection of Microalgae) was used to determine if microalgal cells could be encapsulated and if the capsules were impermeable. The preparation of agar-gelatin-based microcapsules was modified after Lam et al. [50]. Agar ( $2 \%$ in Milli-Q water; Sigma-Aldrich, St Louis, MO, USA) and gelatin (1\% in Milli-Q water; Sigma-Aldrich, St Louis, MO, USA), solutions were mixed in glass beakers using a magnetic stirrer (Labnet International, Inc. AccuPlate ${ }^{\mathrm{TM}}$, Edison, NJ, USA) at $80^{\circ} \mathrm{C}$ until fully dissolved. In a separate beaker, $10 \mathrm{~mL}$ of each solution was added and stirred at $1000 \mathrm{rpm}$ $\left(10 \mathrm{~min}, 60^{\circ} \mathrm{C}\right.$ ). Alexandrium minutum culture (ca. 5000 cells $\mathrm{mL}^{-1} ; 10 \mathrm{~mL}$ ) was added to the agar-gelatin mixture and this mixture was stirred for a further $5 \mathrm{~min}(1000 \mathrm{rpm}, \mathrm{RT})$. A solution of olive oil ( $400 \mathrm{~mL}$; extra-virgin) and Span ${ }^{\circledR} 80$ (2 mL; Sigma-Aldrich, St Louis, MO, USA) was made up separately and the mixture slowly added to the agar-gelatinalgae solution with continuous stirring at $1000 \mathrm{rpm}$. This was then homogenised (OMNI International, $\operatorname{Inc}^{\circledR}, 1 \mathrm{~min}$ ) to create an emulsion. The emulsion was left to cool whilst stirring (1000 rpm, $3 \mathrm{~h}$ ). Following stirring, the solution was transferred into a separating funnel along with $500 \mathrm{~mL}$ of sterile seawater to promote separation from the oil causing the microcapsules to aggregate at the bottom layer of the separating funnel. The capsules were collected, washed three times with acetone, filtered through $100 \mu \mathrm{m}$ and $20 \mu \mathrm{m}$ filters until all olive oil was removed, rinsed with tap water and then dispersed in seawater.

\subsubsection{Tetrodotoxin Encapsulation}

The encapsulation method was subsequently trialled using liquid TTX solution $\left(0.7 \mathrm{mg} \mathrm{kg}^{-1}\right)$ in lieu of a biological producer. Unfortunately, due to the high solubility of TTX in water, the capsules did not contain any toxin after encapsulation (results not shown). Liquid TTX was then substituted for TTX bound to solid humic acid, a strong chelator, to create a solid substrate to encapsulate. To validate that TTX was binding to the humic acid before adding it to the capsules, a small experiment was undertaken where TTX $\left(10 \mu \mathrm{L}, 6 \mathrm{mg} \mathrm{kg}^{-1}\right)$ was diluted in MilliQ-water $(1 \mathrm{~mL})$, before adding humic acid $(60 \mathrm{mg}$; Sigma-Aldrich, St Louis, MO, USA) and vortexing ( 2 min, max. speed). Finally, formic acid $(10 \mu \mathrm{L},>98 \%$; Sigma-Aldrich, St Louis, MO, USA) was added to the solution to investigate the release of TTX from the particles of humic acid and simulate what would happen in the stomach of $P$. australis ( $\mathrm{pH} \sim 4$, as measured in this study). Sub-samples of the solution were taken at each step and analysed for TTX concentration (see methods below).

After ensuring that TTX was binding to humic acid, the TTX solution $(500 \mu \mathrm{L}$; $\left.0.7 \mathrm{mg} \mathrm{kg}^{-1}\right)$ was diluted in Milli-Q water $(9500 \mu \mathrm{L})$ and added to humic acid (500 mg) which was then vortexed (5 $\mathrm{min})$. The protocol described in 4.2.1 was then undertaken using TTX-humic acid solution instead of A. minutum cells. Three test individuals of $P$. australis were fed the capsule solution and sacrificed $24 \mathrm{~h}$ later. Their digestive glands were dissected before being observed under the microscope. The final concentration of TTX in the capsule solution and its accumulation rate in individual P. australis were calculated using the formula:

$$
\% \text { TTX accumulated }=\frac{\text { amount TTX }(\mu \mathrm{g}) \text { in each organ }- \text { amount TTX }(\mu \mathrm{g}) \text { in controls }}{506 \mu \mathrm{L} \text { LTX given } \times 0.007 \mathrm{~L} \times \text { number of TTX feedings }} \times 100
$$

\subsubsection{Microscopic Characterization of Microcapsules}

For the entire method development, microcapsules were microscopically examined using an CKX41 microscope (Olympus, Tokyo, Japan) equipped with a digital camera. Digital images were captured and processed using the cellSens imaging acquisition software (Olympus Life Science, version 1.12, Tokyo, Japan). 


\subsection{Feeding Experiment}

Following the acclimation period, P. australis of similar size were transferred to individual 1-L glass jars $(n=1$ per jar) containing $500 \mathrm{~mL}$ of filtered seawater with constant aeration. The bivalves $(n=20)$ were individually fed a mixture of concentrated I. galbana $\left(93 \mathrm{~mL}\right.$; ca. $12 \times 10^{12}$ cells $\mathrm{mL}^{-1}$ ) and freshly-made TTX capsules $(7 \mathrm{~mL})$ five times at days $0,3,6,9$ and 12 , or were fed I. galbana only on the same days for experimental controls. The mixture of TTX and algae instead of TTX capsules only was used to trigger the P. australis to open and start filtering their food. A subsample $(50 \mathrm{~mL})$ of I. galbana culture was collected and analysed for TTX. Five P. australis fed TTX microcapsules were harvested on day 7, along with five control individuals. The remaining P. australis (five fed the solution of I. galbana and TTX capsules and five fed I. galbana only) were harvested on day 13 for TTX analysis. Using the weight and TTX concentration from each tissue sample and the total weight of individual $P$. australis, total TTX concentrations in whole organisms were calculated. Faeces samples were harvested from each jar at days 7 and 13 but on closer inspection, we observed that these samples also contained humic acid particles that had aggregated at the bottom of the jar and it was not possible to separate these. No further analysis was undertaken on the faeces as it would not have provided meaningful data. The jars were cleaned and the water was replaced on day 7. At each sampling point, P. australis were rinsed with Milli-Q water, left to drain $(5 \mathrm{~min})$ and were frozen $\left(-20^{\circ} \mathrm{C}\right)$ until toxin extraction.

\subsubsection{Tetrodotoxin Extraction and Analysis Using Liquid Chromatography Tandem-Mass Spectrometry}

The TTX extraction protocol was adapted from Biessy et al. (2018). Frozen P. australis were shucked, aseptically dissected into two tissue groups: (1) the siphons and digestive gland combined (DGS), and (2) the "rest" mostly composed of the foot, gonads, gills and mantle. Each sample was weighed (ca. $0.3-3 \mathrm{~g}$ for the different organs) and placed in a sterile tube $(50 \mathrm{~mL})$ containing a corresponding volume (ca. $300-3000 \mu \mathrm{L})$ of $1 \%$ acetic acid in Milli-Q water. The samples were then homogenised (OMNI International, Inc ${ }^{\circledR}$, Kennesaw, GA, USA; 45 s or until complete homogenisation). Samples were boiled ( $5 \mathrm{~min}$ ) and cooled in an ice bath $(5 \mathrm{~min})$ followed by brief vortexing. The samples were centrifuged $(3200 \times \mathrm{g}, 10 \mathrm{~min})$ and $1 \mathrm{~mL}$ of the supernatant was transferred to a centrifuge tube $(1.7 \mathrm{~mL})$ containing $5 \mu \mathrm{L}$ of $25 \%$ ammonia (Honeywell, Charlotte, NC, USA). The samples were centrifuged again $(17,000 \times g, 1 \mathrm{~min})$ and the supernatant was cleaned with the GPC Solid Phase Extraction (SPE) method (Boundy et al., 2015) using Supelclean ENVICarb $250 \mathrm{mg} / 3 \mathrm{~mL}$ SPE cartridges (Sigma-Aldrich, St Louis, MO, USA). The extracted tetrodotoxin was analysed and quantified using liquid chromatography tandem-mass spectrometry as described in Turner et al. (2017).

\subsubsection{Statistical Analysis}

The effect of time, sample type, and their interactions on TTX accumulation were assessed using a mixed effect linear model [51]. This modelling framework addresses the non-independence of the data, considering the individual P. australis. "Animal id" was incorporated into the model as a random effect. TTX concentration was log-transformed to linearize the relationship and reduce heteroscedasticity. The log-transformed TTX data were tested for normality with an Anderson-Darling normality test [52]. The marginal means for the combination of the day, sample type and TTX concentrations were estimated and the comparisons among them. Adjusted $p$ values for the differences were calculated using the Tukey method. All statistical analyses were performed within the ' $R$ ' statistical and programming environment [53]. The package lme4 [54] was used for the mixed effect linear models and the package emmeans [55] to estimate the marginal means (least-squares means) for the factor combinations from the mixed-effects linear models. 


\section{Conclusions}

A method which involved binding TTX to solid particles of humic acid and encapsulating them in agar-gelatin capsules was successfully developed. This is the first study binding TTX to a solid particle that was then fed to aquatic organisms. This experiment involved a known quantity of TTX-containing microcapsules being fed to P. australis. The bivalves only accumulated 0.5 to $1 \%$ of the TTX given at each feeding but their TTX concentrations reached of up to $103 \mu \mathrm{g} \mathrm{kg}{ }^{-1}$ after only 13 days, a concentration similar to those found in wild populations and well above the safe threshold recommended by EFSA of $44 \mu \mathrm{g} \mathrm{kg}^{-1}$ in bivalves. This result demonstrated that $P$. australis can accumulate TTX from an external source, thus strengthening the hypothesis that bivalves accumulate TTX from their diet. The method developed in this study will enable TTX dynamics to be explored within different species of bivalves, and other aquatic species. Enhancing knowledge on accumulation and depuration rates in a range of aquatic species will help establish the time needed for safe consumption to occur following the discovery of contamination with TTX, and may provide new insights into why some bivalves accumulate TTX and others do not.

Author Contributions: L.B., I.H., K.F.S. and S.A.W. conceived and designed the experiments. L.B. performed the experiments, analysed the results and wrote the first draft of the manuscript. K.F.S., I.H. and S.A.W. helped with the data interpretation. R.v.G., A.T., and J.R.D.B. helped with the method development and the experiment. All authors contributed to the editing and writing of the manuscript and approved the final submitted manuscript.

Funding: This work was supported by the MBIE-funded Safe New Zealand Seafood Research Programme (contract No.: CAWX1801), a PhD scholarship from the New Zealand Food Safety Science \& Research Centre to Laura Biessy, and the Cawthron Institute Internal Capability Investment Fund.

Institutional Review Board Statement: Not applicable.

Informed Consent Statement: Not applicable.

Data Availability Statement: Not applicable.

Acknowledgments: The authors thank Paula Casanova (Cawthron) for statistical help, Sophie Young (Cawthron) for laboratory assistance, and Jonathan Puddick (Cawthron) for his advice on encapsulation.

Conflicts of Interest: The authors declare no conflict of interest.

\section{References}

1. James, K.J.; Carey, B.; O’Halloran, J.; Škrabáková, Z. Shellfish toxicity: Human health implications of marine algal toxins. Epidemiol. Infect. 2010, 138, 927-940. [CrossRef] [PubMed]

2. Huss, H.H. Control of indigenous pathogenic bacteria in seafood. Food Control. 1997, 8, 91-98. [CrossRef]

3. Özogul, F.; Hamed, I. Marine-Based Toxins and Their Health Risk. In Food Quality: Balancing Health and Disease; Elsevier: Amsterdam, The Netherlands, 2018; pp. 109-144.

4. Whittle, K.; Gallacher, S. Marine toxins. Br. Med Bull. 2000, 56, 236-253. [CrossRef] [PubMed]

5. Hallegraeff, G.M. Harmful algal blooms: A global overview. Man. Harmful Mar. Microalgae 2003, 33, 1-22.

6. Visciano, P.; Schirone, M.; Berti, M.; Milandri, A.; Tofalo, R.; Suzzi, G. Marine biotoxins: Occurrence, toxicity, regulatory limits and reference methods. Front. Microbiol. 2016, 7, 1051. [CrossRef]

7. Harada, T.; Oshima, Y.; Kamiya, H.; Yasumoto, T. Confirmation of paralytic shellfish toxins in the dinoflagellate Pyrodinium bahamense var. compressa and bivalves in Palau. Nippon Suisan Gakkaishi 1982, 48, 821-825. [CrossRef]

8. Murray, S.A.; Wiese, M.; Neilan, B.A.; Orr, R.J.S.; de Salas, M.; Brett, S.; Hallegraeff, G. A reinvestigation of saxitoxin production and sxtA in the 'non-toxic' Alexandrium tamarense Group V clade. Harmful Algae 2012, 18, 96-104. [CrossRef]

9. Negri, A.; Stirling, D.; Quilliam, M.; Blackburn, S.; Bolch, C.; Burton, I.; Eaglesham, G.; Thomas, K.; Walter, J.; Willis, R. Three novel hydroxybenzoate saxitoxin analogues isolated from the dinoflagellate Gymnodinium catenatum. Chem. Res. Toxicol. 2003, 16, 1029-1033. [CrossRef]

10. Shin, H.H.; Li, Z.; Réveillon, D.; Rovillon, G.-A.; Mertens, K.N.; Hess, P.; Kim, H.J.; Lee, J.; Lee, K.-W.; Kim, D.; et al. Centrodinium punctatum (Dinophyceae) produces significant levels of saxitoxin and related analogs. Harmful Algae 2020, 10, 101923. [CrossRef]

11. Moustafa, A.; Loram, J.E.; Hackett, J.D.; Anderson, D.M.; Plumley, F.G.; Bhattacharya, D. Origin of saxitoxin biosynthetic genes in cyanobacteria. PLoS ONE 2009, 4, e5758. [CrossRef]

12. Pearson, L.; Mihali, T.; Moffitt, M.; Kellmann, R.; Neilan, B. On the chemistry, toxicology and genetics of the cyanobacterial toxins, microcystin, nodularin, saxitoxin and cylindrospermopsin. Mar. Drugs 2010, 8, 1650-1680. [CrossRef] [PubMed] 
13. Quiblier, C.; Wood, S.A.; Echenique-Subiabre, I.; Heath, M.; Villeneuve, A.; Humbert, J.-F. A review of current knowledge on toxic benthic freshwater cyanobacteria-ecology, toxin production and risk management. Water Res. 2013, 47, 5464-5479.

14. Kwong, R.W.M.; Wang, W.-X.; Lam, P.K.S.; Peter, K.N. The uptake, distribution and elimination of paralytic shellfish toxins in mussels and fish exposed to toxic dinoflagellates. Aquat. Toxicol. 2006, 80, 82-91. [CrossRef] [PubMed]

15. Pereira, P.; Dias, E.; Franca, S.; Pereira, E.; Carolino, M.; Vasconcelos, V. Accumulation and depuration of cyanobacterial paralytic shellfish toxins by the freshwater mussel Anodonta cygnea. Aquat. Toxicol. 2004, 68, 339-350. [CrossRef] [PubMed]

16. Chau, R.; Kalaitzis, J.A.; Neilan, B.A. On the origins and biosynthesis of tetrodotoxin. Aquat. Toxicol. 2011, 104, 61-72. [CrossRef]

17. Bane, V.; Lehane, M.; Dikshit, M.; O’Riordan, A.; Furey, A. Tetrodotoxin: Chemistry, toxicity, source, distribution and detection. Toxins 2014, 6, 693-755. [CrossRef]

18. Noguchi, T.; Arakawa, O. Tetrodotoxin-distribution and accumulation in aquatic organisms, and cases of human intoxication. Mar. Drugs 2008, 6, 220-242. [CrossRef]

19. Wu, Z.; Yang, Y.; Xie, L.; Xia, G.; Hu, J.; Wang, S.; Zhang, R. Toxicity and distribution of tetrodotoxin-producing bacteria in puffer fish Fugu rubripes collected from the Bohai Sea of China. Toxicon 2005, 46, 471-476. [CrossRef]

20. Katikou, P. Public health risks associated with tetrodotoxin and its analogues in European waters: Recent advances after The EFSA scientific opinion. Toxins 2019, 11, 240. [CrossRef]

21. Cardall, B.L.; Brodie, E.D.; Hanifin, C.T. Secretion and regeneration of tetrodotoxin in the rough-skin newt (Taricha granulosa). Toxicon 2004, 44, 933-938. [CrossRef]

22. Yotsu-Yamashita, M.; Mebs, D.; Yasumoto, T. Tetrodotoxin and its analogues in extracts from the toad Atelopus oxyrhynchus (family: Bufonidae). Toxicon 1992, 30, 1489-1492. [CrossRef]

23. Lago, J.; Rodríguez, L.P.; Blanco, L.; Vieites, J.M.; Cabado, A.G. Tetrodotoxin, an extremely potent marine neurotoxin: Distribution, toxicity, origin and therapeutical uses. Mar. Drugs 2015, 13, 6384-6406. [CrossRef] [PubMed]

24. Biessy, L.; Boundy, M.J.; Smith, K.F.; Harwood, D.T.; Hawes, I.; Wood, S.A. Tetrodotoxin in marine bivalves and edible gastropods: A mini-review. Chemosphere 2019, 236, 124404. [CrossRef] [PubMed]

25. Salvitti, L.; Wood, S.A.; Taylor, D.I.; McNabb, P.; Cary, S.C. First identification of tetrodotoxin (TTX) in the flatworm Stylochoplana sp.; a source of TTX for the sea slug Pleurobranchaea maculata. Toxicon 2015, 95, 23-29. [CrossRef] [PubMed]

26. Okabe, T.; Oyama, H.; Kashitani, M.; Ishimaru, Y.; Suo, R.; Sugita, H.; Itoi, S. Toxic Flatworm Egg Plates Serve as a Possible Source of Tetrodotoxin for Pufferfish. Toxins 2019, 11, 402. [CrossRef]

27. Espinosa, E.P.; Barillé, L.; Allam, B. Use of encapsulated live microalgae to investigate pre-ingestive selection in the oyster Crassostrea gigas. J. Exp. Mar. Biol. Ecol. 2007, 343, 118-126. [CrossRef]

28. Vidhyalakshmi, R.; Bhakyaraj, R.; Subhasree, R.S. Encapsulation "the future of probiotics"-a review. Adv. Biol. Res. 2009, 3, 96-103.

29. Masoomi Dezfooli, S.; Gutierrez-Maddox, N.; Alfaro, A.; Seyfoddin, A. Encapsulation for delivering bioactives in aquaculture. Rev. Aquac. 2019, 11, 631-660. [CrossRef]

30. Turner, A.; Powell, A.; Schofield, A.; Lees, D.; Baker-Austin, C. Detection of the pufferfish toxin tetrodotoxin in European bivalves, England, 2013 to 2014. Eurosurveillance 2015, 20, 2-8. [CrossRef]

31. Biessy, L.; Smith, K.F.; Harwood, D.T.; Boundy, M.J.; Hawes, I.; Wood, S.A. Spatial variability and depuration of tetrodotoxin in the bivalve Paphies australis from New Zealand. Toxicon X 2019, 2, 100008. [CrossRef]

32. McNabb, P.S.; Taylor, D.I.; Ogilvie, S.C.; Wilkinson, L.; Anderson, A.; Hamon, D.; Wood, S.A.; Peake, B.M. First detection of tetrodotoxin in the bivalve Paphies australis by liquid chromatography coupled to triple quadrupole mass spectrometry with and without precolumn reaction. J. AOAC Int. 2014, 97, 325-333. [CrossRef]

33. Riisgård, H.U. Efficiency of particle retention and filtration rate in 6 species of Northeast American bivalves. Mar. Ecol. Prog. Ser. 1988, 45, 217-223. [CrossRef]

34. Cognie, B.; Barillé, L.; Massé, G.; Beninger, P.G. Selection and processing of large suspended algae in the oyster Crassostrea gigas. Mar. Ecol. Prog. Ser. 2003, 250, 145-152. [CrossRef]

35. Boundy, M.J.; Biessy, L.; Roughan, B.; Nicolas, J.; Harwood, D.T. Survey of tetrodotoxin in New Zealand bivalve molluscan shellfish over a 16-month period. Toxins 2020, 12, 512. [CrossRef] [PubMed]

36. Biessy, L.; Pearman, J.K.; Smith, K.F.; Hawes, I.; Wood, S.A. Seasonal and spatial variations in bacterial communities from tetrodotoxin-bearing and non-tetrodotoxin-bearing clams. Front. Microbiol. 2020, 11, 1860. [CrossRef]

37. Wood, S.A.; Casas, M.; Taylor, D.I.; McNabb, P.; Salvitti, L.; Ogilvie, S.; Cary, S.C. Depuration of tetrodotoxin and changes in bacterial communities in Pleurobranchea maculata adults and egg masses maintained in captivity. J. Chem. Ecol. 2012, 38, 1342-1350. [CrossRef]

38. Knutsen, H.K.; Alexander, J.; BarregAard, L.; Bignami, M.; Brüschweiler, B.; Ceccatelli, S.; Cottrill, B.; Dinovi, M.; Edler, L.; Grasl-Kraupp, B. Risks for public health related to the presence of tetrodotoxin (TTX) and TTX analogues in marine bivalves and gastropods. Eur. Food Saf. Auth. J. 2017, 15, e04752. [CrossRef]

39. Li, Z.; Tian, J.; Lai, Y.; Lee, C.-H.; Cai, Z.; Yu, C.-F. Puffer fish gut microbiota studies revealed unique bacterial co-occurrence patterns and new insights on tetrodotoxin producers. Mar. Drugs 2020, 18, 278. [CrossRef]

40. Paerl, H.W.; Paul, V.J. Climate change: Links to global expansion of harmful cyanobacteria. Water Res. 2012, 46, 1349-1363. [CrossRef] 
41. Baker-Austin, C.; Trinanes, J.A.; Taylor, N.G.H.; Hartnell, R.; Siitonen, A.; Martinez-Urtaza, J. Emerging Vibrio risk at high latitudes in response to ocean warming. Nat. Clim. Chang. 2013, 3, 73-77. [CrossRef]

42. Oikawa, H.; Satomi, M.; Watabe, S.; Yano, Y. Accumulation and depuration rates of paralytic shellfish poisoning toxins in the shore crab Telmessus acutidens by feeding toxic mussels under laboratory controlled conditions. Toxicon 2005, 45, 163-169. [CrossRef] [PubMed]

43. Yotsu-Yamashita, M.; Sugimoto, A.; Terakawa, T.; Shoji, Y.; Miyazawa, T.; Yasumoto, T. Purification, characterization, and cDNA cloning of a novel soluble saxitoxin and tetrodotoxin binding protein from plasma of the puffer fish, Fugu pardalis. Eur. J. Biochem. 2001, 268, 5937-5946. [CrossRef] [PubMed]

44. Nagashima, Y.; Yamamoto, K.; Shimakura, K.; Shiomi, K. A tetrodotoxin-binding protein in the hemolymph of shore crab Hemigrapsus sanguineus: Purification and properties. Toxicon 2002, 40, 753-760. [CrossRef]

45. Biessy, L.; Smith, K.F.; Boundy, M.J.; Webb, S.; Hawes, I.; Wood, S.A. Distribution of tetrodotoxin in the New Zealand clam, Paphies australis, established using immunohistochemistry and liquid chromatography-tandem quadrupole mass spectrometry. Toxins 2018, 10, 282. [CrossRef] [PubMed]

46. Kvitek, R.; Bretz, C. Harmful algal bloom toxins protect bivalve populations from sea otter predation. Mar. Ecol. Prog. Ser. 2004, 271, 233-243. [CrossRef]

47. Kvitek, R.G. Paralytic shellfish toxins sequestered by bivalves as a defense against siphon-nipping fish. Mar. Biol. 1991, 111, 369-374. [CrossRef]

48. Bricelj, V.M.; Shumway, S.E. Paralytic shellfish toxins in bivalve molluscs: Occurrence, transfer kinetics, and biotransformation. Rev. Fish. Sci. 1998, 6, 315-383. [CrossRef]

49. Martin, J.L.; White, A.W.; Sullivan, J.J. Anatomical distribution of paralytic shellfish toxins in soft-shell clams. Toxic Mar. Phytoplankton 1990, 379-384.

50. Lam, P.-L.; Lee, K.K.-H.; Kok, S.H.-L.; Cheng, G.Y.-M.; Tao, X.-M.; Hau, D.K.-P.; Yuen, M.C.-W.; Lam, K.-H.; Gambari, R.; Chui, C.-H. Development of formaldehyde-free agar/gelatin microcapsules containing berberine $\mathrm{HCl}$ and gallic acid and their topical and oral applications. Soft Matter 2012, 8, 5027-5037. [CrossRef]

51. Zuur, A.; Ieno, E.N.; Walker, N.; Saveliev, A.A.; Smith, G.M. Mixed Effects Models and Extensions in Ecology with R., 1st ed.; Springer Science \& Business Media: New York, NY, USA, 2009; p. 574.

52. Thode, H.C. Testing for Normality; CRC press: New York, NY, USA, 2002; Volume 164.

53. RCoreTeam. R: A language and environment for statistical computing. 2020. https://www.r-project.org/.

54. Bates, D.; Mächler, M.; Bolker, B.; Walker, S. Fitting linear mixed-effects models using lme4. J. Stat. Softw. 2015, 67, 1-48. [CrossRef]

55. Lenth, R.; Singmann, H.; Love, J.; Buerkner, P.; Herve, M. Emmeans: Estimated marginal means, aka least-squares means. 2020. https://rdrr.io/cran/emmeans/. 